\title{
Differential sensitivity of Desi (small-seeded) and Kabuli (large-seeded) chickpea genotypes to water stress during seed filling: effects on accumulation of seed reserves and yield
}

\author{
Harsh Nayyar, ${ }^{1 *}$ Satwinder Kaur, ${ }^{1}$ Smita Singh ${ }^{2}$ and Hari D Upadhyaya ${ }^{3}$ \\ ${ }^{1}$ Department of Botany, Panjab University, Chandigarh 160 014, India \\ ${ }^{2}$ Department of Plant Biology, University of New Hampshire, Durham, NH 03824, USA \\ ${ }^{3}$ International Crop Research Institute for Semi-Arid Tropics, Hyderabad, India
}

\begin{abstract}
Water stress during the reproductive phase, especially during seed development, is considered detrimental for chickpea yield. In the present study, the relative sensitivity of Desi and Kabuli chickpea types to water stress during seed filling was assessed in terms of effects on quantitative and qualitative aspects of seed yield. Leaves of both types experienced stress injury (evaluated as electrolyte leakage) to the same extent and possessed almost similar values of water potential at the end of 14 days of water stress. The stressed plants of Kabuli type lost more chlorophyll and had less photosynthesis than Desi type. At maturity, Desi type showed more diminution of vegetative dry matter due to stress over control than Kabuli type. On the other hand, Kabuli type showed a proportionally greater reduction in seed weight per plant, average seed weight, average seed size, number of pods (single- and double-seeded) and harvest index. The stressed seeds of Kabuli type showed 48 and $46 \%$ reduction over control in starch and protein content compared with 25 and $40 \%$, respectively in Desi type. The accumulation of soluble sugars was relatively greater due to stress in Kabuli (47\%) than Desi type (23\%). Fat and fiber content declined by 39 and $35 \%$ over control in Desi seeds because of stress whereas Kabuli type showed 46 and 67\% decreases, respectively. Protein fractions, namely albumins, globulins, glutelins and prolamins, decreased in stressed seeds of Kabuli by 32, 40, 16 and $15 \%$ over control relative to 40, 48, 30 and $28 \%$, respectively, in Kabuli type. The activities of sucrose synthase, invertase and soluble starch synthase were inhibited to a higher extent in Kabuli seeds than Desi seeds under stress. Kabuli seeds showed significantly more reduction in the accumulation of amino acids such as phenylalanine + tyrosine, tryptophan, valine, alanine and histidine and minerals (Ca, $\mathbf{P}$, Fe) due to stress compared with Desi type.

(C) 2006 Society of Chemical Industry
\end{abstract}

Keywords: chickpea; drought; seed development; Desi; Kabuli; water stress

\section{INTRODUCTION}

Chickpea (Cicer arietinum L.) is the third most important grain legume crop in the world and first in the Mediterranean basin and South Asia. ${ }^{1}$ It has one of the highest nutritional compositions of any dry edible legume with an average of $220 \mathrm{~g} \mathrm{~kg}^{-1}$ protein, $670 \mathrm{~g} \mathrm{~kg}^{-1}$ total carbohydrates, $470 \mathrm{~g} \mathrm{~kg}^{-1}$ starch, $50 \mathrm{~g} \mathrm{~kg}^{-1}$ fat, $80 \mathrm{~g} \mathrm{~kg}^{-1}$ crude fiber and $36 \mathrm{~g} \mathrm{~kg}^{-1}$ ash. Two types of chickpea are recognized, Desi (colored, small seeded, angular and fibrous) and Kabuli (beige, large seeded, rams-head shaped with lower fiber content) type with slight variations in their seed composition. ${ }^{2}$

Chickpea frequently experiences water stress during pod set and seed filling (terminal drought) in India and the Mediterranean basin, leading to a substantial reduction in its seed yield. ${ }^{3}$ Water stress during seed filling has been reported to be highly detrimental to yield in several other crops such as wheat, ${ }^{4}$ rice, ${ }^{5}$ barley, ${ }^{6}$ beans ${ }^{7}$ and chickpea. ${ }^{8}$ While examining the effects of water stress during flowering and seed filling, Leport et $a l^{9}$ reported 50-80\% reductions in seed yield due to restrictions in photosynthesis. Moreover, water stress has also been reported to retard mobilization of assimilates to developing seeds due to inhibition in activity of enzymes involved in sucrose and nitrogen metabolism in source and sinks. ${ }^{4}$

Relatively, fewer studies have been reported on the impact of water stress during seed development on the chemical composition of seeds. Dwivedi et al ${ }^{10}$ observed a decrease in oil content and an increase in protein concentrations in seeds of groundnut plants exposed to terminal drought. Behboudian et $a l^{11}$ found that water stress during seed development in chickpea led to an increase in the nutritive value of chickpea seeds in terms of higher accumulation of sugars, amino 
acids and proteins. Carvalho et al ${ }^{12}$ observed that water stress did not affect the protein content but reduced the oil content to half in lupin seeds while the sugar content increased. Particularly, information on relative effects of water stress on Desi and Kabuli types, especially on their seed composition, is lacking. Hence the objective of this study was to assess the comparative response of two chickpea types to water deficits imposed during the seed filling stage in terms of seed yield and seed composition along with the possible mechanisms governing the variation, if any, between the two types.

\section{MATERIALS AND METHODS}

\section{Raising of plants}

Plants of Desi (cv. GPF2) and Kabuli (cv. L550) types were raised in earthen pots (height $30 \mathrm{~cm}$, diameter $25 \mathrm{~cm}$, volume $14.72 \mathrm{~L}$ ) having a mixture of air-dry soil, sand and farmyard manure in a ratio of $2: 1: 1$ $(\mathrm{v} / \mathrm{v} / \mathrm{v})$ and recommended doses of fertilizers. The soil was loam with a $\mathrm{pH}$ of 7.1. The seeds were inoculated with Rhizobium ciceri ${ }^{13}$ at the recommended rate of $1.95 \mathrm{~g} \mathrm{~kg}^{-1}$ seeds. Four seeds were planted in each pot in November and, after emergence, the plants were thinned to two per pot.

\section{Application of water stress}

The plants were subjected to water stress at a stage when they had set $7-9$ pods per plant by withholding water for 14 days. Water potential and photosynthesis of the leaves were measured in stressed and control plants between 10.00 and 11.00 a.m. Pods of the branches at the upper three nodes were tagged for analysis of seed parameters.

\section{Stress injury and chlorophyll determination}

These were examined on the leaf samples (uppermost leaves) using electrolyte leakage (EL) and chlorophyll content as markers. For EL, leaves were washed with deionized water to remove surface-adhered electrolytes. ${ }^{14}$ They were placed in closed vials containing $10 \mathrm{~mL}$ of deionized water and incubated at $25^{\circ} \mathrm{C}$ on a rotary shaker for $24 \mathrm{~h}$ and subsequently the electrical conductivity of the solution $\left(L_{1}\right)$ was determined. Samples were then autoclaved at $120^{\circ} \mathrm{C}$ for $20 \mathrm{~min}$ and the final electrical conductivity $\left(L_{2}\right)$ was obtained after equilibration at $25^{\circ} \mathrm{C}$. The EL was defined as EL $(\%)=\left(L_{1} / L_{2}\right) \times 100$. Chlorophyll was extracted with $80 \%$ acetone from samples of fresh leaves gathered from control and stressed plants. The extract was measured spectrophotometrically at 645 and $663 \mathrm{~nm} .^{15}$

\section{Enzyme assays}

Activity levels of enzymes (sucrose synthase, soluble starch synthase and invertase) were assayed on fresh seeds harvested at physiological maturity from pods of the upper three nodes. For enzyme assays, samples (500 mg; three replications) were homogenized in the presence of ice-cold $200 \mathrm{mmol} \mathrm{L}^{-1} \mathrm{HEPES}-\mathrm{KOH}$ buffer ( $\mathrm{pH} 7.8$ ), containing $3 \mathrm{mmol} \mathrm{L}^{-1} \quad \mathrm{Na}_{2}$ EDTA. $2 \mathrm{H}_{2} \mathrm{O}, 3 \mathrm{mmol} \mathrm{L}^{-1}$ magnesium acetate, $10 \mathrm{mmol} \mathrm{L}^{-1}$ dithiothreitol (DTT) and $10 \mathrm{~g} \mathrm{~L}^{-1}$ polyvinylpyrrolidone (PVP). The homogenate was centrifuged $(10000 \times g)$ for $20 \mathrm{~min}$ at $4{ }^{\circ} \mathrm{C}$ and the supernatant was used directly as enzyme and protein source. The activity of invertase (EC 3.2.1.26), soluble starch synthase (EC 2.4.1.21) and sucrose synthase (EC 2.4.1.13) were assayed according to $\mathrm{Xu}$ et $a l^{16}$ and Sung et al, ${ }^{17}$ respectively. Assays were performed at $25^{\circ} \mathrm{C}$ in a final volume of $1 \mathrm{~mL}$.

\section{Analysis of seed reserves}

The mature seeds of control and stressed plants were analyzed for various seed reserves. Soluble sugars and starch were extracted with ethanol $950 \mathrm{mLL}^{-1}$ and $300 \mathrm{mLL}^{-1}$ perchloric acid, respectively. Both components were quantified by the phenol-sulfuric acid method of Dubois et $a l^{18}$ using glucose (Sigma, St Louis, MO, USA; D9434) as a standard. Ash content, crude protein (micro-Kjeldahl, $\mathrm{N} \times 6.25$ ), crude fat, crude fiber and nutrients were analyzed by standard AOAC procedures. ${ }^{19}$ Sucrose, glucose and fructose were measured by gas chromatography according to the method of Liu and van Staden. ${ }^{20}$ The protein fractions, albumins, globulins, prolamins and glutelins were extracted sequentially from seeds according the method of Triboï et al. ${ }^{21}$ Briefly, seeds were ground to whole meal flour. During each extraction step, the samples were stirred continuously on a magnetic stirrer for $60 \mathrm{~min}$. Soluble and insoluble fractions were separated by centrifugation at $8000 \times g$ for $30 \mathrm{~min}$ at the extraction temperature. Albumins and globulins were extracted at $4{ }^{\circ} \mathrm{C}$ with $25 \mathrm{~mL}$ of $0.05 \mathrm{~mol} \mathrm{~L}^{-1}$ sodium phosphate buffer $(\mathrm{pH} 7.8)$ and $0.05 \mathrm{~mol} \mathrm{~L}^{-1} \mathrm{NaCl}$ solution, respectively. Amphiphilic proteins were extracted at $4^{\circ} \mathrm{C}$ from the previous pellet with $25 \mathrm{~mL}$ of $20 \mathrm{mLL}^{-1}$ Triton $\mathrm{X}-114$, $0.1 \mathrm{~mol} \mathrm{~L}^{-1} \mathrm{NaCl}, 0.05 \mathrm{~mol} \mathrm{~L}^{-1}$ sodium phosphate buffer ( $\mathrm{pH} 7.8$ ). Prolamins were extracted at $20^{\circ} \mathrm{C}$ from the previous pellet with $25 \mathrm{~mL}$ of $700 \mathrm{mLL}^{-1}$ ethanol. Glutelins were extracted at $20^{\circ} \mathrm{C}$ from the previous pellet with $25 \mathrm{~mL}$ of $20 \mathrm{~g} \mathrm{~L}^{-1}$ sodium dodecyl sulfate (SDS), $20 \mathrm{ml} \mathrm{L}^{-1}$ 2-mercaptoethanol (2-SH), $0.05 \mathrm{~mol} \mathrm{~L}^{-1}$ tetraborate buffer ( $\mathrm{pH} 8.5$ ). After centrifugation, the glutelins were recovered in the supernatant. The protein content of each fraction was determined according to Lowry et al. ${ }^{22}$ Amino acid analysis was conducted with an amino acid analysis system following the method of Bourgoin. ${ }^{23}$ This involved precolumn derivatization of the free amino acids with 6-aminoquinoline followed by separation on a $\mathrm{C}_{18}$ HPLC column with fluorescence detection.

\section{Seed growth rate and seed filling duration}

For the investigation of seed growth rate and seed filling duration, 25 plants growing under control and stressed conditions were examined. Five pods per 
plant were tagged at the beginning of pod filling (pod size $\sim 1 \mathrm{~cm}$ ) and followed until physiological maturity of the seeds. The dry weight of the seeds was recorded 7 days after initiation of pod filling and at physiological maturity the seeds were oven dried at $45^{\circ} \mathrm{C}$ for 5 days and their weight was recorded. The time (days) required to complete the seed filling was noted in tagged pods.

\section{Yield parameters}

The number of pods (single-seeded, double-seeded and infertile) was recorded from 25 plants of each type and treatments. The seed weight and seed size were recorded in 100 pods of each treatment.

Observations were replicated in triplicate and data were analyzed for means and standard errors. Analysis of variance (ANOVA) was conducted for each parameter and the least significant difference (LSD) was calculated.

\section{RESULTS}

Leaves of the water-stressed plants of both the types experienced stress injury (as electrolyte leakage) to almost the same extent [Fig. 1(a)]. Leaf water potential also decreased to a similar level in both types [Fig. 1(b)]. In Kabuli type, the chlorophyll content [Fig. 2(a)] decreased due to stress to a significantly higher degree ( $47 \%$ over control) than Desi type (20\% over control). Similarly, the photosynthetic rate (Pn) in stressed plants was reduced by $58 \%$ in Desi type compared with $71 \%$ in Kabuli type [Fig. 2(b)].

At maturity, the stressed plants of Kabuli genotype showed a smaller reduction (28\% over control) in vegetative dry mass than Desi type (34\%) (Table 1). The seed growth rate showed $31 \%$ inhibition over control due to water stress in Desi type compared with $47 \%$ in Kabuli type. The duration of seed filling was decreased to 11 days in stressed plants of Kabuli type compared with 14 days in Desi type. The number of seeds per 100 pods in Desi type decreased to 95 over


Figure 1. Effect of water stress during seed filling on electrolyte leakage (a) and leaf water potential (b) of Desi and Kabuli chickpea types. Vertical bars represent standard errors.

its control (126) whereas in Kabuli type it declined to 56 over its control (106). The average seed weight of stressed plants was lowered by $43 \%$ in Desi type compared with $58 \%$ in Kabuli type. Consequently, the seed yield per plant decreased by 66 and $80 \%$ in Desi and Kabuli types, respectively. A reduction of $22 \%$ in

Table 1. Effect of water stress during seed filling on yield traits of control and stressed plants of Desi and Kabuli chickpea types: values represent mean \pm standard error; values in a row followed by same letter are not significantly different from each other $(P<0.05)$

\begin{tabular}{lccccc}
\hline & \multicolumn{2}{c}{ Desi type } & & \multicolumn{2}{c}{ Kabuli type } \\
\cline { 5 - 6 } \cline { 5 - 6 } Parameter & Control & Stressed & & Control & Stressed \\
\hline Vegetative dry matter (g per plant) including pod wall & $6.8 \pm 1.1 \mathrm{~b}$ & $4.5 \pm 1.2 \mathrm{c}$ & & $10.0 \pm 1.2 \mathrm{a}$ & $7.2 \pm 1.3 \mathrm{~b}$ \\
Seed weight per plant (g) & $5.5 \pm 0.6 \mathrm{a}$ & $1.85 \pm 0.4 \mathrm{~b}$ & & $5.2 \pm 0.8 \mathrm{a}$ & $1.0 \pm 0.4 \mathrm{c}$ \\
Total weight per plant (g) & $12.3 \pm 1.3 \mathrm{~b}$ & $6.3 \pm 1.4 \mathrm{~d}$ & & $15.1 \pm 1.2 \mathrm{a}$ & $8.2 \pm 1.3 \mathrm{c}$ \\
Harvest index & $0.44 \pm 0.11 \mathrm{a}$ & $0.26 \pm 0.13 \mathrm{c}$ & & $0.34 \pm 0.10 \mathrm{~b}$ & $0.12 \pm 0.11 \mathrm{~d}$ \\
Seed growth rate (mg per seed per day) & $8.9 \pm 0.68 \mathrm{~b}$ & $6.1 \pm 0.74 \mathrm{c}$ & & $9.6 \pm 0.57 \mathrm{a}$ & $5.1 \pm 0.61 \mathrm{~d}$ \\
Seed fill duration (days) & $19.9 \pm 1.4 \mathrm{a}$ & $14.0 \pm 1.3 \mathrm{~b}$ & & $20.2 \pm 1.3 \mathrm{a}$ & $11.0 \pm 1.2 \mathrm{c}$ \\
Seed number per 100 pods & $126 \pm 3.1 \mathrm{a}$ & $95 \pm 2.6 \mathrm{c}$ & & $106 \pm 3.1 \mathrm{~b}$ & $56 \pm 4.1 \mathrm{~d}$ \\
Average seed weight (mg) & $172 \pm 2.6 \mathrm{~b}$ & $98.2 \pm 3.4 \mathrm{c}$ & & $239 \pm 2.5 \mathrm{a}$ & $100 \pm 6.4 \mathrm{c}$ \\
Average seed size (mm) & $6.8 \pm 0.6$ & $5.3 \pm 0.8$ & & $8.1 \pm 1.3$ & $5.1 \pm 1.6$ \\
Pods per plant & $26.9 \pm 2.1 \mathrm{a}$ & $14.9 \pm 2.6 \mathrm{c}$ & & $19.9 \pm 2.7 \mathrm{~b}$ & $10.3 \pm 3.1 \mathrm{~d}$ \\
Single-seeded per plant & $22.2 \pm 2.2 \mathrm{a}$ & $12.9 \pm 2.4 \mathrm{c}$ & & $17.8 \pm 1.6 \mathrm{~b}$ & $9.0 \pm 1.8 \mathrm{~d}$ \\
Double-seeded per plant & $4.7 \pm 1.1 \mathrm{a}$ & $2.0 \pm 0.8 \mathrm{~b}$ & & $2.1 \pm 0.7 \mathrm{~b}$ & $0.8 \pm 0.2 \mathrm{c}$ \\
Infertile pods per plant (\%) & $6.2 \pm 1.4 \mathrm{c}$ & $9.6 \pm 1.6 \mathrm{a}$ & & $8.6 \pm 0.6 \mathrm{a}$ & $21.0 \pm 0.7 \mathrm{~d}$ \\
\hline
\end{tabular}



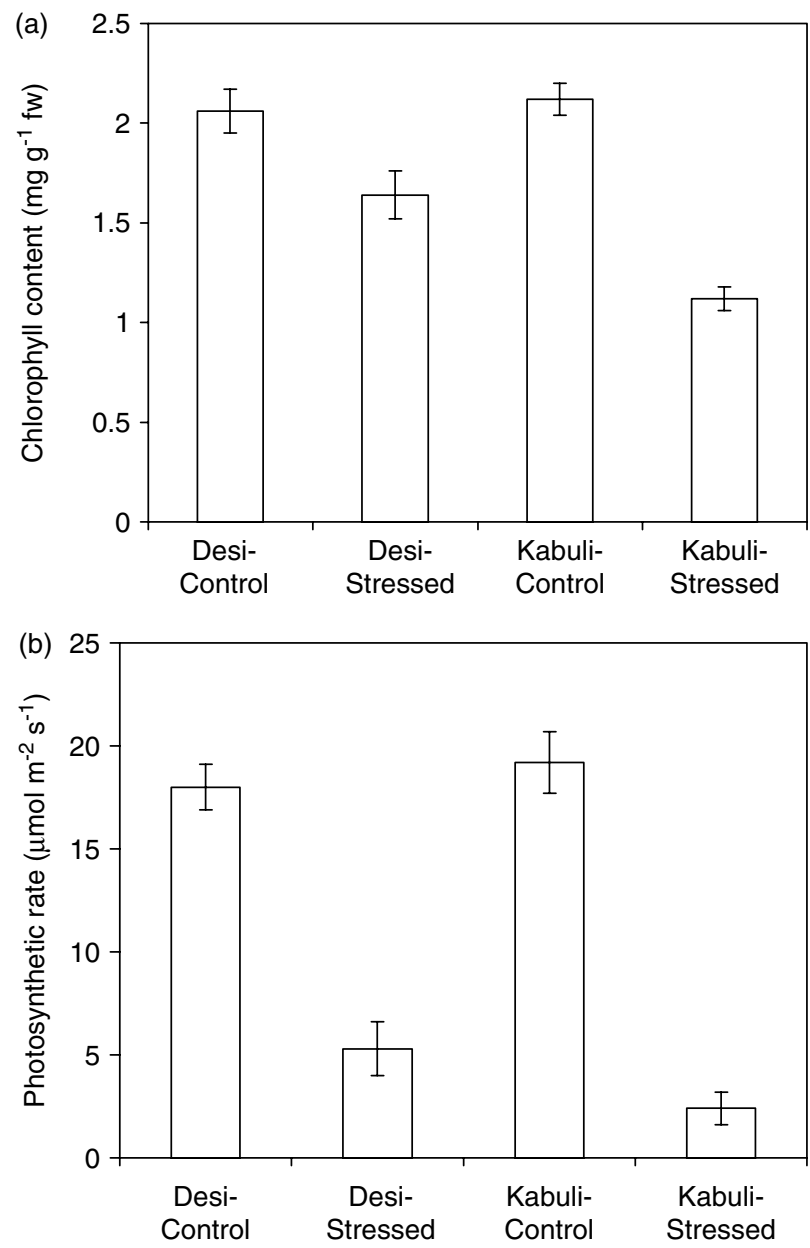

Figure 2. Effect of water stress during seed filling on chlorophyll content (a) and photosynthetic rate (b) of Desi and Kabuli chickpea types. Vertical bars represent standard errors.

average seed size was observed in water-stressed plants of Desi type compared with $38 \%$ in Kabuli type. The stressed plants of Desi type had $41 \%$ fewer fertile pods over control compared with $60 \%$ for Kabuli type. The number of double-seeded pods declined to a great extent in both the types but Desi type showed a $56 \%$ decrease compared with a $62 \%$ decrease for Kabuli type. Single seeded pods decreased by 41 and $56 \%$ in Desi and Kabuli types, respectively. The number of infertile pods increased in stressed plants by $21 \%$ in Kabuli type and 9\% in Desi type. The harvest index in stressed plants was reduced to a much greater extent in Kabuli than Desi type (Table 1).

Proximate analysis of seeds showed a significant reduction in accumulation of reserves in stressed seeds with more damage to Kabuli type than Desi type [Fig. 3(a)]. Thus in Desi type, starch and proteins showed 25 and $40 \%$ decreases over control, respectively, whereas Kabuli showed 48 and $46 \%$ reductions, respectively. The accumulation of soluble sugars was relatively greater over control in Kabuli type $(47 \%)$ than Desi type $(23 \%)$. The fat and fiber contents diminished by 39 and $35 \%$, respectively, in Desi type compared with 46 and $67 \%$, respectively, in Kabuli type.
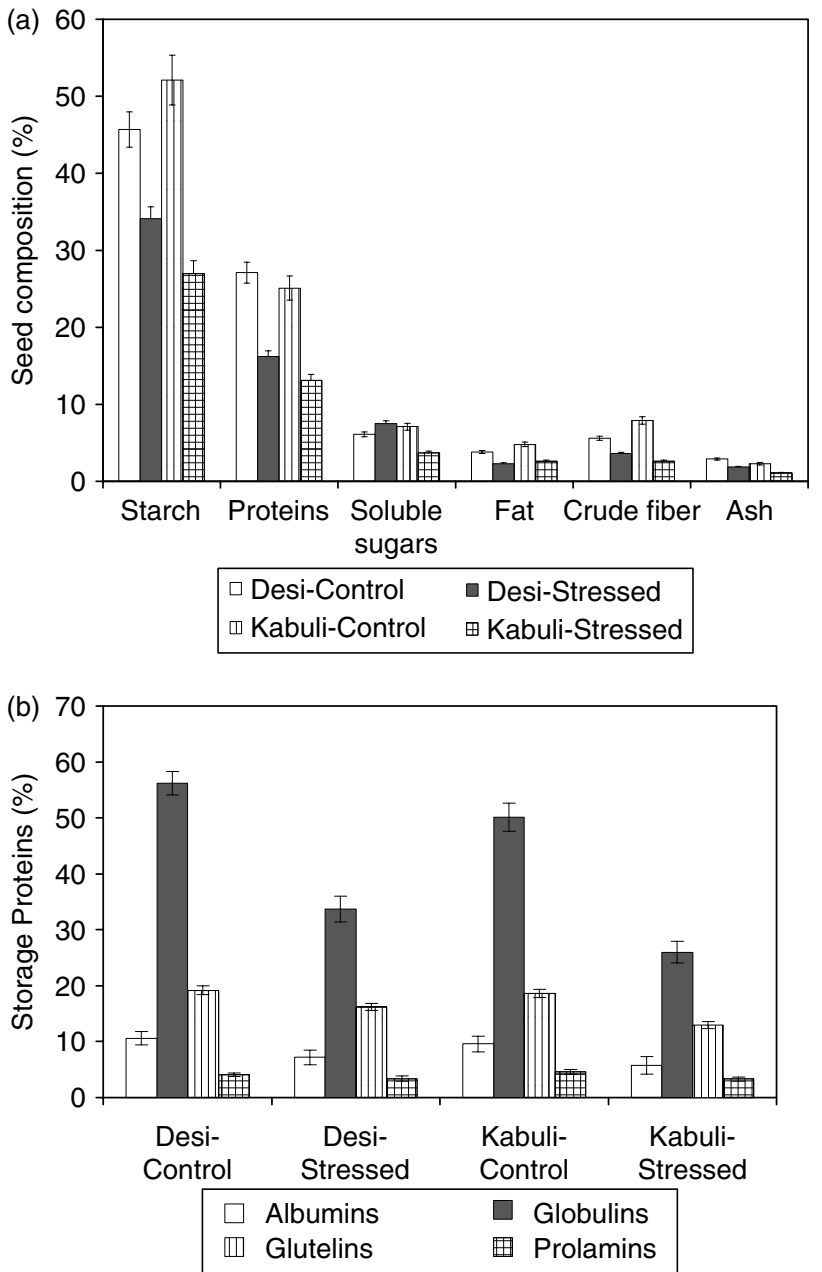

Figure 3. Effect of water stress during seed filling on seed composition (a) and protein fractions (b) of Desi and Kabuli chickpea types. Vertical bars represent standard errors.

Observations on fractions of seed proteins revealed proportionately higher reductions due to stress in albumins and globulins than glutelins and prolamins, and more so in Kabuli type [Fig. 3(b)]. The decreases in Desi type for albumins, globulins, glutelins and prolamins were $32,40,16$ and $15 \%$, respectively, over control compared with corresponding decreases of 40 , 48,30 and $28 \%$, respectively, in Kabuli type.

Sucrose accumulation was higher in stressed seeds of Kabuli type (46\% over control) than Desi type ( $34 \%$ over control), whereas the converse was true for glucose and fructose (Table 2). The activity of sucrose synthase, soluble starch synthase and invertase were inhibited to a greater extent in Kabuli type (49, 44 and $47 \%$ over control, respectively) than Desi type (26, 34 and $30 \%$ over control, respectively). The accumulation of minerals such as calcium, phosphorus and iron was restricted more in Kabuli than Desi type (Table 2).

Amino acids such as arginine, glutamic acid, glycine, isoleucine, leucine and proline increased significantly in stressed seeds of both types (Table 3). Phenylalanine + tyrosine, tryptophan, valine, alanine and histidine declined to a significantly greater extent in stressed seeds of Kabuli than Desi type. Arginine, 
Table 2. Effect of water stress during seed filling on soluble sugars, enzymes and minerals of seeds harvested at physiological maturity from control and stressed plants of Desi and Kabuli chickpea types: values represent mean \pm standard error; values in a row followed by same letter are not significantly different from each other $(P<0.05)$

\begin{tabular}{|c|c|c|c|c|}
\hline \multirow[b]{2}{*}{ Parameter } & \multicolumn{2}{|c|}{ Desi type } & \multicolumn{2}{|c|}{ Kabuli type } \\
\hline & Control & Stressed & Control & Stressed \\
\hline Sucrose $\left(\mu \mathrm{mol} \mathrm{g}{ }^{-1} \mathrm{DM}\right)$ & $38.2 \pm 2.3 b$ & $51.1 \pm 3.1 \mathrm{a}$ & $36.7 \pm 2.6 b$ & $53.1 \pm 2.8 \mathrm{a}$ \\
\hline Glucose ( $\left.\mu \mathrm{mol} \mathrm{g}{ }^{-1} \mathrm{DM}\right)$ & $7.5 \pm 1.6 \mathrm{~d}$ & $9.6 \pm 1.3 a$ & $8.2 \pm 1.5 c$ & $9.8 \pm 1.3 a$ \\
\hline Fructose $\left(\mu \mathrm{mol} \mathrm{g}^{-1} \mathrm{DM}\right)$ & $7.1 \pm 1.4 \mathrm{c}$ & $9.8 \pm 1.2 \mathrm{a}$ & $7.5 \pm 1.3 c$ & $8.6 \pm 1.2 \mathrm{~b}$ \\
\hline Sucrose synthase (nmol min ${ }^{-1} \mathrm{mg}^{-1}$ protein) & $66.6 \pm 3.1 b$ & $49.2 \pm 2.6 \mathrm{c}$ & $71.6 \pm 3.4 a$ & $36.3 \pm 3.7 d$ \\
\hline Soluble starch synthase (nmol min ${ }^{-1} \mathrm{mg}^{-1}$ protein) & $2589 \pm 11.6 a$ & $1700 \pm 23.1 c$ & $2428 \pm 53.4 b$ & $1368 \pm 46.1 d$ \\
\hline Invertase (nmol $\mathrm{min}^{-1} \mathrm{mg}^{-1}$ protein) & $2046 \pm 33.2 b$ & $1426 \pm 38.6 c$ & $2147 \pm 41.2 \mathrm{a}$ & $1125 \pm 36.1 d$ \\
\hline Calcium $\left(\mathrm{g} \mathrm{kg}^{-1}\right)$ & $2.6 \pm 0.4 a$ & $2.1 \pm 0.2 b$ & $2.6 \pm 0.3 a$ & $2.0 \pm 0.08 c$ \\
\hline Phosphorus $\left(\mathrm{g} \mathrm{kg}^{-1}\right)$ & $2.5 \pm 0.3 a$ & $1.4 \pm 0.4 b$ & $2.4 \pm 0.2 \mathrm{a}$ & $1.2 \pm 0.1 c$ \\
\hline Iron $\left(\mathrm{g} \mathrm{kg}^{-1}\right)$ & $0.18 \pm 0.2 a$ & $0.11 \pm 0.02 b$ & $0.19 \pm 0.03 a$ & $0.08 \pm 0.02 c$ \\
\hline
\end{tabular}

Table 3. Effect of water stress during seed filling on amino acid composition ( $\mu \mathrm{mol} \mathrm{g}^{-1} \mathrm{DM}$ ) of whole seeds of control and stressed plants of Desi and Kabuli chickpea types: values represent mean \pm standard error; values in a row followed by same letter are not significantly different from each other $(P<0.05)$

\begin{tabular}{|c|c|c|c|c|}
\hline \multirow[b]{2}{*}{ Parameter } & \multicolumn{2}{|c|}{ Desi type } & \multicolumn{2}{|c|}{ Kabuli type } \\
\hline & Control & Stressed & Control & Stressed \\
\hline Arginine & $4.1 \pm 0.3 d$ & $5.2 \pm 0.2 b$ & $4.6 \pm 0.2 c$ & $5.8 \pm 0.3 a$ \\
\hline Glutamic acid & $1.3 \pm 0.2 d$ & $1.8 \pm 0.3 b$ & $1.6 \pm 0.12 c$ & $2.0 \pm 0.11 \mathrm{a}$ \\
\hline Glycine & $2.1 \pm 0.4 d$ & $3.1 \pm 0.4 b$ & $2.6 \pm 0.2 c$ & $3.4 \pm 0.16 a$ \\
\hline Isoleucine & $4.1 \pm 0.5 b$ & $4.8 \pm 0.6 a$ & $3.4 \pm 0.13 c$ & $4.1 \pm 0.2 b$ \\
\hline Leucine & $6.2 \pm 0.3 a$ & $7.0 \pm 0.2 a$ & $5.8 \pm 0.2 c$ & $6.7 \pm 0.3 a$ \\
\hline Lysine & $4.4 \pm 0.6 a$ & $4.1 \pm 0.4 a$ & $4.6 \pm 0.3 a$ & $2.5 \pm 0.3 b$ \\
\hline Methionine + cystine & $2.0 \pm 0.4 a$ & $1.2 \pm 0.3 c$ & $1.8 \pm 0.2 b$ & $1.1 \pm 0.2 c$ \\
\hline Phenylalanine + tyrosine & $7.1 \pm 0.5 b$ & $6.2 \pm 0.4 c$ & $7.6 \pm 0.2 a$ & $5.3 \pm 0.4 d$ \\
\hline Proline & $4.8 \pm 0.5 c$ & $6.6 \pm 0.5 b$ & $4.3 \pm 0.4 c$ & $7.1 \pm 0.5 a$ \\
\hline Threonine & $3.8 \pm 0.7 a$ & $2.6 \pm 0.2 c$ & $3.1 \pm 0.2 b$ & $2.2 \pm 0.3 c$ \\
\hline Tryptophan & $1.8 \pm 0.4 a$ & $0.9 \pm 0.15 c$ & $1.5 \pm 0.3 b$ & $0.6 \pm 0.1 d$ \\
\hline Valine & $3.2 \pm 0.12 \mathrm{a}$ & $2.4 \pm 0.13 c$ & $2.9 \pm 0.18 b$ & $2.1 \pm 0.16 d$ \\
\hline Alanine & $2.8 \pm 0.8 a$ & $2.6 \pm 0.7 a$ & $2.3 \pm 0.4 a$ & $1.5 \pm 0.3 b$ \\
\hline Histidine & $2.8 \pm 0.8 a$ & $3.0 \pm 0.6 a$ & $2.4 \pm 0.4 a$ & $1.2 \pm 0.4 b$ \\
\hline Aspartic acid & $1.3 \pm 0.7 a$ & $1.0 \pm 0.8 a$ & $1.4 \pm 0.3 a$ & $1.2 \pm 0.2 \mathrm{a}$ \\
\hline Serine & $1.5 \pm 0.5 a$ & $1.6 \pm 0.7 a$ & $1.6 \pm 0.3 a$ & $1.3 \pm 0.3 a$ \\
\hline
\end{tabular}

glutamic acid, glycine and proline were present at significantly higher levels in Kabuli than Desi type.

\section{DISCUSSION}

The present findings indicate that water stress during seed filling has a pronounced inhibitory effect on quantitative and qualitative aspects of chickpea seeds. The findings in this context substantiate previous reports of reductions in seed quality ${ }^{11}$ and yield ${ }^{24}$ in chickpea plants subjected to water stress during the reproductive phase. Seed development in chickpea is reported to be impaired by water stress because of restrictions in production and mobilization of photoassimilates to the developing seeds. ${ }^{24}$ These limitations might arise due to water stress-induced damage at several levels of organization in the plants. ${ }^{25}$ Here, a marked increase in electrolyte leakage of the leaf tissues of the stressed plants was found, suggesting injury to the membranes. Coupled with this was a reduction in chlorophyll content and photosynthetic rate in stressed plants of both chickpea types, implying limitations in production of photoassimilates. These abnormalities might occur due to a notable decrease in leaf water potential of the stressed plants indicating appreciable water deficit in the leaves. These observations match those of Leport et al, ${ }^{9}$ who also observed a significant lowering of water potential and Pn in chickpea plants experiencing terminal drought in a Mediterranean-type environment.

The decrease in size and weight of the seeds of stressed plants may be associated with a decline in duration of seed filling and seed growth rate that possibly are the result of damage to photosynthesis by stress. It has been reported previously that in legumes, the growth rate of seeds decreases if the photosynthetic activity is not sufficient to fulfill the assimilate demand of filling seeds. ${ }^{3}$ Our observations in this regard are 
in line with some earlier reports where a reduction in seed size was observed in water-stressed plants due to shortening of the seed filling period in the case of wheat ${ }^{4}$ and soybean. ${ }^{26}$ The decrease in pod number in stressed plants in the present studies was due to abortion of the existing pods and cessation of subsequent pod set (data not presented). This may be the consequence of reduced Pn that is unable to sustain the pods and is in agreement with earlier observations on lupin, ${ }^{27}$ soybean ${ }^{28}$ and chickpea. ${ }^{11}$ The number of infertile pods increased markedly in stressed plants, pointing towards impairment of seed development, which is in agreement with the observations of Davies et $a l^{8}$ in chickpea, who ascribed the results to restrictions in assimilates for seed development due to inhibited photosynthesis and reduced water status. Past studies ${ }^{9}$ on chickpea observed $50-80 \%$ reduction in seed yield in drought-stressed plants of chickpea that was attributed to decreases in seed size, seed number, pod number and increase in unfilled pods.

Accumulations of seed components such as starch, proteins (different fractions, especially albumins and globulins), fat, fiber and ash decreased markedly in stressed plants whereas sugars increased significantly in both types. One of the reasons cited for the decrease in starch accumulation in stressed seeds, as in the case of cereal grains, is the reduced capacity of the endosperm due to a decrease in amyloplasts. ${ }^{29}$ This may also explain the decrease in rate and duration of the dry matter accumulation in stressed seeds. ${ }^{29}$ Additionally, biosynthesis of these molecules may be inhibited in water-stressed seeds. ${ }^{4}$ In the present case, an appreciable reduction in sucrose-cleaving enzymes (invertase, sucrose synthase) was found, which might restrict the availability of glucose precursors for incorporation into starch. Moreover, the activity of soluble starch synthase, a starch-synthesizing enzyme, was also found to be lower in stressed seeds, which might be due to either reduced availability of glucose or because of direct effects of water stress on enzymes. These observations match to some extent those of Hawker and Jenner, ${ }^{30}$ who reported a diminution in the activities of starch-synthesizing enzymes in wheat grains experiencing heat stress. Similarly, Vishwanathan and Chopra ${ }^{31}$ reported a marked reduction in proteins in wheat grains that were heat stressed during their development, which was attributed to either their degradation or impaired synthesis. The increase in sugars and amino acids in seeds due to stress in the present studies is in agreement with the observations of Behboudian et al, ${ }^{11}$ which might be related to inhibition of the utilization of these molecules or their participation in turgor generation in water-stressed seeds. ${ }^{32}$

In the present study, a distinctive variation was found between Desi and Kabuli types in their response to water stress. Although both types experienced similar degrees of water deficit, as indicated by their leaf water potential values, Kabuli type showed greater decreases in chlorophyll content and Pn than Desi type, indicating a higher sensitivity of the former type to water stress. These findings are in contrast to those of Leport et al, ${ }^{9}$ who observed no major difference between the two types for Pn but a higher chlorophyll content in Kabuli genotype under water stress conditions. These variations could be explained by genetic differences. Leport et al also noted that Kabuli type had more green leaves (38\%) than Desi type $(26 \%)$ under these conditions. This was attributed to greater allocation of assimilates towards maintenance of vegetative growth in Kabuli type, unlike in Desi type, which transferred a relatively greater amount of assimilates towards developing seeds. In this context, a similar situation appeared to exist in the present studies since a proportionately higher vegetative dry weight at maturity was found in stressed plants of Kabuli type than Desi type.

Kabuli type also experienced greater impairment of seed development, as revealed by the relatively larger reduction in its size, weight and number of seeds. This might be associated with comparatively lower Pn in this type, which possibly would reduce its ability to produce assimilates to a greater extent. Moreover, the presence of relatively higher vegetative dry matter at maturity in Kabuli type than Desi type also reflects its lower ability to remobilize the assimilates towards developing pods and seeds. The same reason might possibly result in the loss of more pods and a higher number of infertile pods in Kabuli type. Previous studies $^{24}$ in this regard indicated that under water deficit conditions, Kabuli type showed 48 and $66 \%$ reductions in carbon and nitrogen mobilization to seeds, respectively, compared with just 3 and $11 \%$, respectively, in Desi type, which might also explain the lower accumulation of seed reserves such as starch, proteins and minerals in Kabuli type than Desi type. Sucrose showed a larger increase in Kabuli type that might be related to greater inhibition of the activity of enzymes pertaining to the utilization of sucrose for hydrolysis (invertase, sucrose synthase) and starch synthesis (soluble starch synthase) compared with Desi type. The larger reduction in accumulation of minerals such as $\mathrm{Ca}, \mathrm{P}$ and $\mathrm{Fe}$ may perhaps be due to retardation of their transport into the seeds due to stress. ${ }^{33}$ Similarly, all the seed protein fractions decreased to a greater extent in Kabuli type than Desi type. The underlying reasons associated with variations in protein accumulation remain to be investigated. Previously, the water stress-induced decrease in protein fractions and their type in the case of wheat was ascribed to changes in the total quantity of nitrogen per grain. ${ }^{34}$ The elevation of certain amino acids such as proline and glutamic acid in the present studies matches a previous study on seeds of water-stressed Desi chickpea plants. ${ }^{11}$ Proline has been strongly implicated in osmoprotection of water-stressed tissues. ${ }^{32}$ Larger decreases in some amino acids such as lysine, methionine + cystine, phenylalanine + tyrosine, alanine and histidine in Kabuli type than in Desi type are perhaps due to 
greater mobilization restrictions to developing seeds in the former type.

In conclusion, the present studies indicate that water stress at the seed filling phase causes more damage to seed yield and accumulation of seed reserves (starch, proteins, fat, fiber, minerals) in Kabuli type than Desi type of chickpea, which may be attributed to greater inhibition of photosynthesis, higher loss of chlorophyll, lower activities of starch and sucrose metabolism enzymes in seeds and hence possibly lesser ability to mobilize photoassimilates towards developing seeds by the former type than the latter.

\section{REFERENCES}

1 Singh KB and Ocampo B, Exploitation of wild Cicer species for yield improvement in chickpea. Theor Appl Genet 95:418-423 (1997).

2 Malhotra RS, Pundir RPS and Slinkard AE, Genetic resources of chickpea, in The Chickpea, ed. by Saxena MC and Singh KB. CAB International Cambrian News, Aberystwyth, pp. 67-81 (1987)

3 Turner NC, Wright GC and Siddique KHM, Adaptation of grain legumes (pulses) to water-limited environments. Adv Agron 71:193-231 (2001).

4 Yang J, Zhang J, Wang Z, Zhu Q and Liu L, Water deficitinduced senescence and its relationship to remobilization of pre-stored carbon in wheat during grain filling. Agron $\mathcal{f}$ 93:196-206 (2001).

5 Yang J, Zhang J, Wang Z, Zhu Q and Wang W, Hormonal changes in the grains of rice subjected to water stress during grain filling. Plant Physiol 127:315-323 (2001).

6 Samarah NH, Effects of drought stress on growth and yield of barley. Agron Sustain Dev 25:145-149 (2005).

7 Boutraa $\mathrm{T}$ and Sanders FE, Influence of water stress on grain yield and vegetative growth of two cultivars of bean (Phaseolus vulgaris L.). F Agron Crop Sci 187:251-257 (2001).

8 Davies SL, Turner NC, Siddique KHM, Plummer JA and Leport L, Seed growth of desi and Kabuli chickpea (Cicer arietinum L.) in a short-season Mediterranean-type environment. Aust f Exp Agric 39:181-188 (1999).

9 Leport L, Turner NC, French RJ, Barr MD, Duda R, Davies SL, et al, Physiological responses of chickpea genotypes to terminal drought in a Mediterranean-type environment. Eur f Agron 11:279-291 (1999).

10 Dwivedi SL, Nigam SN, Nageswara Rao RC, Singh U and Rao KVS, Effect of drought on oil, fatty acids and protein contents of groundnut (Arachis hypogea L.) seeds. Field Crops Res 48:125-133 (1996).

11 Behboudian MH, Ma Q, Turner NC and Palta JA, Reactions of chickpea to water stress: yield and seed composition. $\mathcal{F ~ S c i}$ Food Agric 81:1288-1291 (2001).

12 Carvalho IS, Chaves $M$ and Pinto Ricardo C, Influence of water stress on the chemical composition of seeds of two lupins (Lupinus albus and Lupinus mutabilis). $\mathcal{F}$ Agron Crop Sci 191:95-98 (2005).

13 Kantar F, Elkoca E, Ogutcu H and Algur OF, Chickpea yields in relation to Rhizobium inoculation from wild chickpea at high altitudes. F Agron Crop Sci 189:291-297 (2003).

14 Lutts S, Kinet JM and Bouharmont J, NaCl-induced senescence in leaves of rice (Oryza sativa L.) cultivars differing in salinity resistance. Ann Bot 78:389-398 (1996).
15 Arnon DI, Copper enzyme in isolated chloroplasts: polyphenol oxidase in Beta vulgaris. Plant Physiol 24:1-15 (1949).

$16 \mathrm{Xu}$ J, Avigne WT, McCarty DR and Koch KE, A similar dichotomy of sugar modulation and development expression affects both paths of sucrose metabolism: evidence from maize invertase gene family. Plant Cell 8:1209-1220 (1996).

17 Sung SS, Kormanik PP, Xu DP and Black CC, Sucrose metabolic pathways in sweetgum and pecan seedlings. Tree Physiol 5:39-52 (1989).

18 Dubois M, Gilles KA and Hamilton JK, Rebers PA and Smith F, Colorimetric method for determination of sugars and related substances. Anal Chem 28:350-356 (1956).

19 Helrich K (ed.), Official Methods of Analysis of the Association of Official Analytical Chemists, Association of Official Analytical Chemists, Arlington, VA, pp. 27 and 84-85 (1990).

20 Liu T and van Staden J, Partitioning of carbohydrates in saltsensitive and salt-tolerant soybean callus cultures under salinity stress and its subsequent relief. Plant Growth Regul 33:13-17 (2001).

21 Triboï E, Abad A, Michelena A, Lloveras J, Ollier JL and Daniel C, Environmental effects on the quality of two wheat genotypes. 1. Quantitative and qualitative variation of storage proteins. Eur F Agron 13:47-64 (2000).

22 Lowry OH, Rosebrough NJ, Farr AL and Randall RJ, Protein measurement with the Folin-phenol reagents. $\mathcal{F}$ Biol Chem 193:265-275 (1951).

23 Bourgoin RF, Determining amino acid composition. Biotechnology 11:1302-1303 (1993).

24 Davies SL, Turner NC, Palta JA, Siddique JHM and Plummer JA, Remobilization of carbon and nitrogen supports seed filling in chickpea subjected to water deficit. Aust F Agric Res 51:855-866 (2000).

25 Chaves MM, Maroco JP and Pereira JS, Understanding plant responses to drought - from genes to the whole plant. Funct Plant Biol 30:239-264.

26 Brevedan RE and Egli DB, Short periods of water stress during seed filling, leaf senescence and yield of soybean. Crop Sci 43:2083-2088 (2003).

27 Dracup M, Reader MA and Palta JA, Variation in yield of narrow-leafed lupin caused by terminal drought. Aust $\mathcal{F}$ Agric Res 49:799-810 (1998).

28 Egli DB, Variation in leaf starch and sink limitations during seed filling in soybean. Crop Sci 39:1361-1368 (1999).

29 Jones RJ, Schreiber BMN and Roessler JA, Kernel sink capacity in maize: genotype and maternal regulation. Crop Sci 36:301-306 (1996).

30 Hawker JS and Jenner CF, High temperature effects on the activity of enzymes in the committed pathways of starch synthesis in developing wheat endosperm. Aust F Plant Physiol 20:197-200 (1993).

31 Vishwanathan C and Chopra RK, Effects of heat stress on grain growth, starch synthesis and protein synthesis in grains of wheat (Triticum aestivum $\mathrm{L}$.) varieties differing in grain weight stability. F Agron Crop Sci 186:1-7 (2001).

32 Delauney AJ and Verma DPS, Proline biosynthesis and osmoregulation in plants. Plant f 4:215-223 (1993).

33 Smiclklas KD, Mullen RE, Carlson RE and Knapp AD, Drought-induced stress effect on soybean seed calcium and quality. Crop Sci 29:1519-1523 (1989).

34 Mossé J, Huet JC and Baudet J, The amino acid composition of wheat grain as a function of nitrogen content. $\mathcal{F}$ Cereal Sci 3:115-130 (1985). 